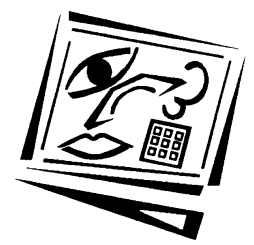

\title{
Designing, developing and implementing a software tool for scenario based learning
}

Geoff Norton, Mathew Taylor The University of Queensland

Terry Stewart Massey University

\author{
Greg Blackburn, Audrey Jinks, Bahareh Razdar, \\ Paul Holmes and Enrique Marastoni \\ The University of Queensland
}

\begin{abstract}
The pedagogical value of problem-based and inquiry-based learning activities has led to increased use of this approach in many courses. While scenarios or case studies were initially presented to learners as text-based material, the development of modern software technology provides the opportunity to deliver scenarios as e-learning modules, providing learners with a more accessible and engaging learning experience. Scenario Based Learning - interactive (SBLi) has been specifically developed to provide teachers and trainers with a generic tool that enables them to easily build interactive, multimedia scenarios without requiring programming skills. The software consists of a builder and player application, for constructing and playing scenarios from hard drives or from a CD/DVD, and a server-based player and manager, for deploying scenarios on the web, either for public use or for restricted and managed use in specific courses. This paper describes the history of SBLi, its design and operational features, how SBLi is being used to achieve innovative and effective learning experiences, and the practical issues that need to be addressed in supporting and sustaining e-learning software such as SBLi.
\end{abstract}

\section{Introduction}

Teaching and learning incorporates many different strategies, ranging from passive rote-learning to more active strategies, where students take more responsibility and become much more engaged in the learning process. These active, often overlapping, strategies include problem-based learning (Barrows \& Tamblyn, 1980; Hmelo-Silver, 2004), inquiry learning (Kuhn, Black, Keselman \& Kaplan, 2000) and case-based learning (Christensen \& Hansen, 1981), to name just a few. The advantages of active over more passive forms of instruction include increased motivation, better critical thinking, and the integration of knowledge and problem-solving skills.

A number of computer-based technologies can assist this more active type of learning, particularly in the hands of a good lesson designer, for example, through the integration of quizzes; fill in forms; and the ability to navigate to specific information pages depending on students' decisions. These features are found in most popular learning management systems (LMS) such as Moodle and Blackboard. 
Scenario-based learning, as an important component of many active learning strategies, engages learners in interactive scenarios or case studies, either as reflective observers or as active participants. In the latter case, learners are required to make decisions, which can offer penalties or rewards and open up, or close off, various future options in the scenario. The software functionality required to immerse students in this type of learning environment, and for teachers to design it, can be quite complex. It requires specifically designed software that goes beyond what current LMS environments can offer.

While a number of discipline or subject specific authoring and delivery tools have been developed to reflect the complexity of real world situations, particularly in medicine (e.g. Virtual Patients, 2011), many attributes of these scenarios are universal whatever the discipline. In recognising these generic features of scenario based learning, a team based at The University of Queensland has developed a suite of software tools to enable teachers and trainers to easily develop interactive multimedia scenario-based lessons, which can be delivered to learners via CD, DVD or online (The University of Queensland, 2012).

This suite of software, known as Scenario Based Learning - interactive, or SBLi for short, consists of:

The SBLi Builder:

The SBLi Player:

The SBLi Server Player: The SBLi Server Manager:
A client based authoring tool for building multimedia scenarios

A client-based player to deliver scenarios locally (on CD or via a local network)

For delivering scenarios over the web, and

To manage the deployment of scenarios on the web

The purpose of this paper is to describe the origins of SBLi and the design and principal features of the SBLi software suite, to illustrate how SBLi has been used to create engaging and instructive scenario-based lessons, and to discuss practical issues associated with supporting and sustaining SBLi.

\section{Background}

SBLi has been designed and developed as a tool for implementing the pedagogical approaches involved in active learning strategies, mentioned above, and incorporating situated learning theory (Brown, Collins \& Duguid, 1989). The aim is to foster synergies between learner, task and technology (Herrington, Reeves \& Oliver, 2004) and to create innovative, immersive and authentic problem-based learning environments for student collaboration and interaction on realistic tasks, behaviours and roles.

The development of Scenario Based Learning - interactive (SBLi) was based on an earlier, pre-web computer-based learning tool, Diagnosis of Crop Problems, developed at the University of Queensland in collaboration with Massey University, New Zealand, and first released in 1994 (Stewart, Blackshaw, Duncan, Dale, Zalucki \& Norton, 1995). Diagnosis for Crop Problems had its conceptual origins in an earlier MS-DOS program called Diagnosis (Stewart, 1992). The software enabled university teachers to develop their own problem scenarios as "virtual case studies", providing students with the experience of diagnosing a range of crop related problems, with much of the complexity they would experience in the real world. 
In 2005, with the availability of new software technology, a specification was developed for SBLi and software development commenced in that year. At the same time as these developments were taking place, Massey University was awarded funds from the New Zealand Government e-learning Collaborative Development Fund (eCDF) to develop and implement a similar generic tool for use in all New Zealand tertiary educational institutions. Since the project was for just 18 months and the SBLi team at the University of Queensland had already developed an advanced prototype of SBLi, an agreement was reached whereby some of the eCDF funds were used to fund SBLi development at The University of Queensland, in return for free licences of the software for all NZ tertiary institutions.

This arrangement enabled the New Zealand project to make an important contribution to the specification and development of SBLi, helping to ensure that SBLi met the requirements for wide-scale use. This strategy also enabled the bulk of the NZ project funds to be used for training in scenario development, and to develop supporting resources and exemplar scenarios.

\section{The design of SBLi}

As described earlier, SBLi consists of a suite of software tools: the SBLi Builder, Player and Server. In the process of designing and developing this SBLi software, account was taken of the authors' experience with Diagnosis of Crop Problems, other scenario-based authoring and delivery prototypes (Stewart \& Bartrum, 2002) and the work of Schank, Fano, Bell \& Jona (1993) on goal-based scenarios. The resulting design is structured on three generic features of a scenario - locations, items and actions.

\section{Locations}

Represent different places within the scenario, which learners can visit. Locations can be places, such as schools, libraries, hospitals, veterinary laboratories and farms, but are not restricted to physical buildings. They could represent rooms within buildings or something completely different, such as animal body parts, fields on a farm, conceptual spaces, such as "reflections", or simply a main activity. Each location can have various Items and Actions associated with it.

\section{Items}

These represent objects within a location which the user can examine, use, perform actions on, or interact with. Some items, if set by the scenario author, can be collected and taken to other locations.

\section{Actions}

Represent an activity that can be performed within the scenario, such as inspecting, monitoring, counting, picking a plant, taking a sample, talking to a scenario character, taking an X-ray, or writing a report. An action is related to a location or to a specific item and can be set to cost virtual time or money.

As well as developing software that is easy to use, another important consideration in designing the SBLi software has been the need to provide an easy transition from the scenario building process to its delivery to users. This has been achieved by using the same "what you see is what you get" interface for the Builder and the Player. Thus, the SBLi Builder has two modes of operation: builder mode and player mode. Scenarios created in builder mode can be easily tested to see how the user will see it, by 
occasionally switching into player mode. This feature is particularly important for testing the pre-requisite function, which is used to determine the availability of specific scenario components, as described below; pre-requisites cannot be tested in builder mode.

The SBLi interface, which incorporates Locations, Items, Actions and information about each of them, consists of 4 windows; see Figures 1 and 2, which show the Builder mode and Player mode respectively.

\section{The Location window}

The top left-hand window shows the different locations within a scenario. When in Builder mode (Figure 1), the toolbar located to the right of the Location window is used to add, select, move, and remove objects within that window.

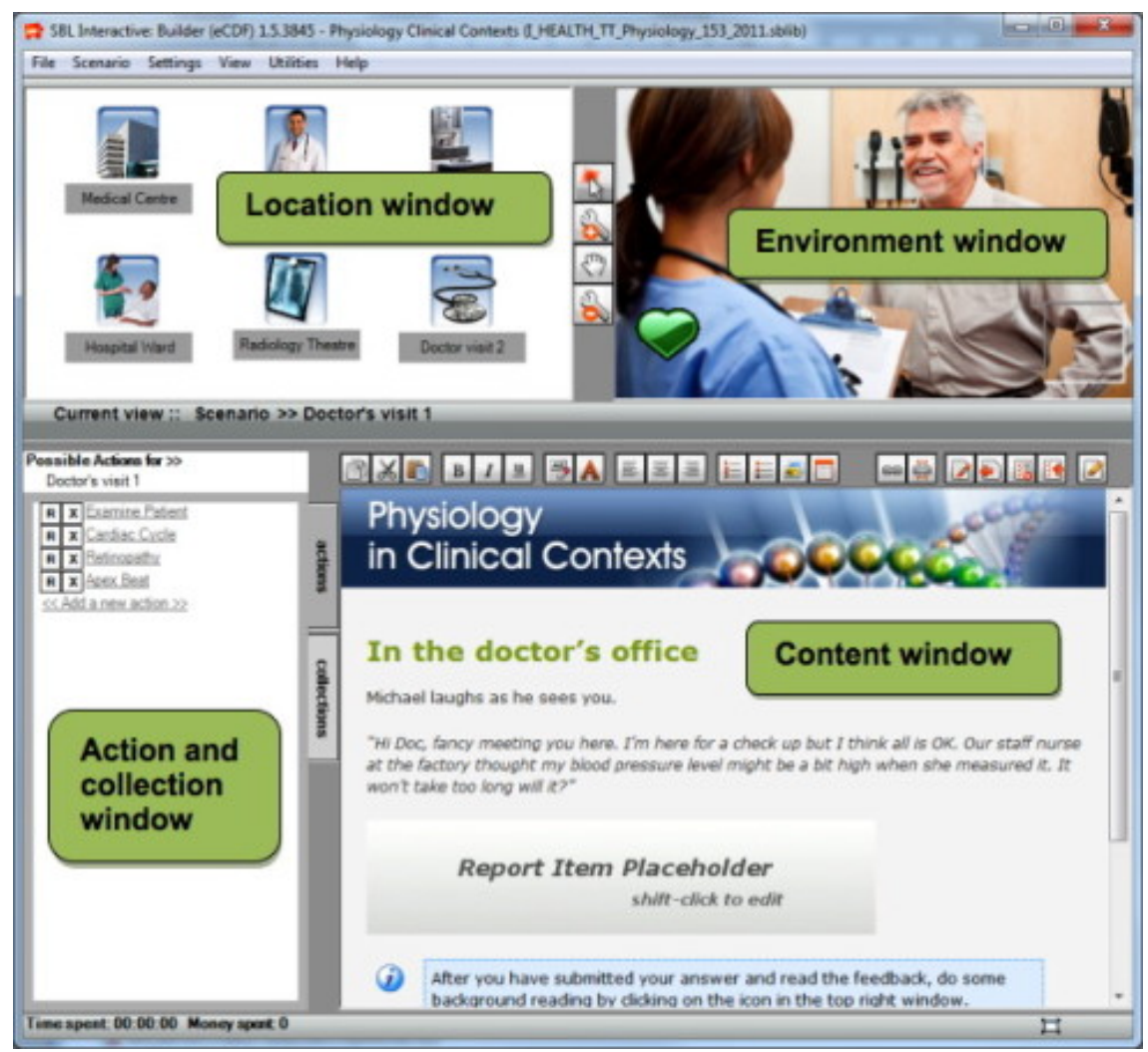

Figure 1: Screen shot of a medical scenario in Builder mode

\section{The Environment window}

The Environment window represents the environment of the location currently being visited. By adding a background image it gives the student a feeling of "being there" (Figure 2). This window shows the Items associated with a Location; Items are added, selected, moved or removed by using the toolbar it shares with the Location Window when in Builder mode (Figure 1). 


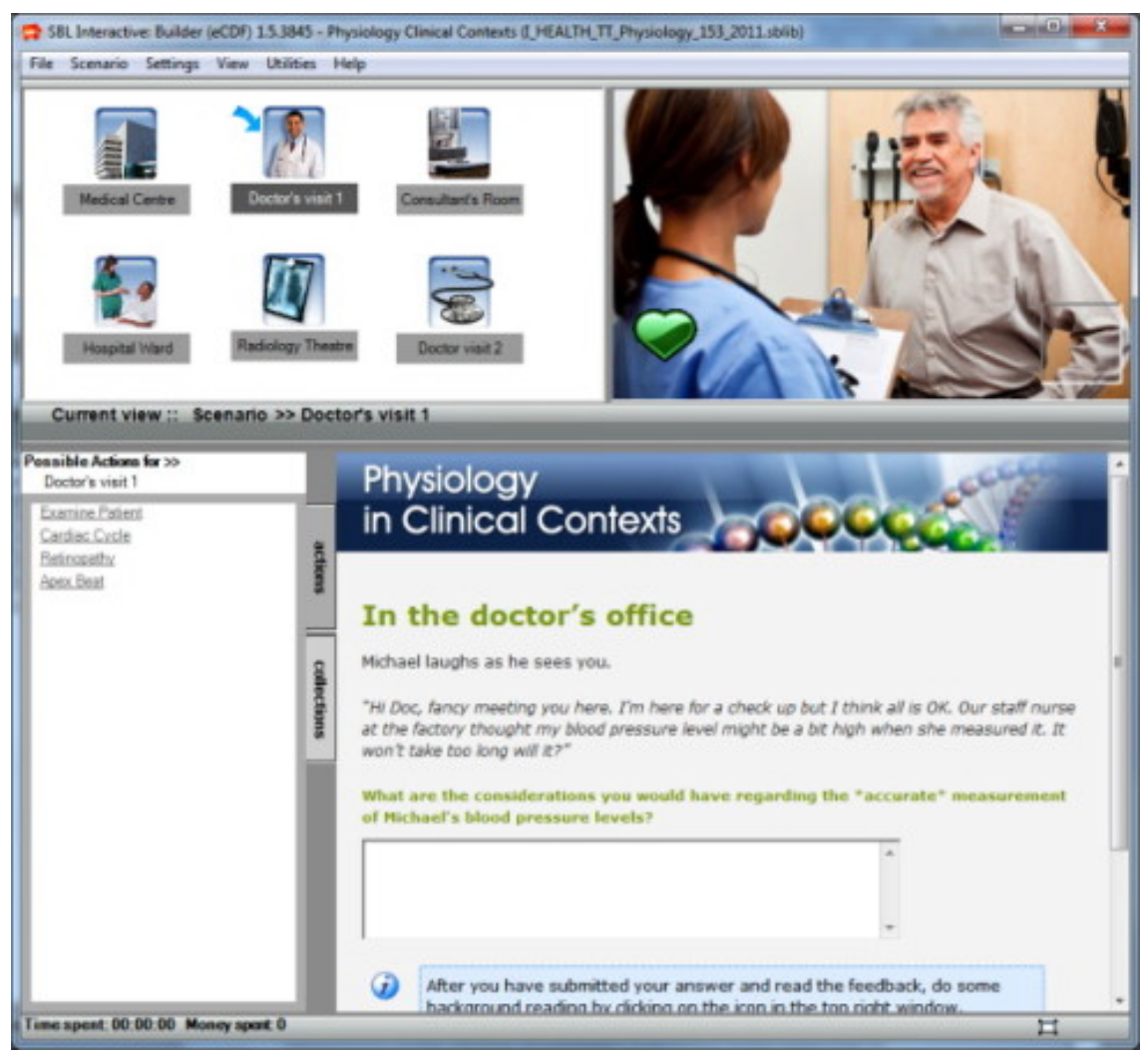

Figure 2: Screen shot of the same medical scenario in Player mode

\section{The Content window}

The lower right hand window is where most of the content for a scenario is delivered. Every Location, Item and Action within a scenario has a content page associated with it. These content pages allow the author of the scenario to explain the story-line to the user and describe what is currently happening and to present testing components. A different content page will appear in this window every time a new Location, Item or Action is selected.

When in Builder mode (see Figure 1), the tool bar above the content window (Figure 3) provides the scenario developer with standard editing functions - such as copy, cut, paste, and hyperlink - as well as a number of special features, which provide authors with much greater scope in making their scenarios attractive and effective. All HTML functionality, including audio and video clips can be included in the content in this window, as well as external web pages, Macromedia Flash, Excel, Word, PowerPoint, and PDF.

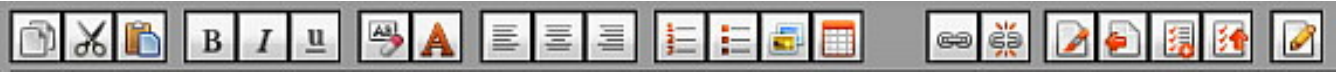

Figure 3: Close up of Content window tool bar seen in Figure 1 
External editors (such as Adobe Dreamweaver) can be accessed via this toolbar as can an incorporated multimedia library that provides assistance to scenario authors wanting to include multimedia in their scenarios. This media resource library makes the incorporation of multimedia into a scenario much easier. As well as containing a set of generic icon images that are pre-loaded, the media library provides functions that enable scenario authors to import, categorise and store other media items, including icons, images, and audio and video clips. Two important features of this media library are the automatic conversion of a range of video and audio files to Flash video and sound for optimised viewing on the Internet, and optional automatic resizing of images and video when inserting them into an SBLi scenario.

\section{The Actions/Collections window}

The lower left hand window, serves as an Actions window and a Collections window, depending on whether the Actions tab or Collections tab is active. The Actions window shows all the actions associated with the current Location or Item, whichever is selected. The Collections window shows any Items that have been collected from the Environment window (see "Collecting items" below), which can then be retrieved in other locations.

\section{The Properties panel}

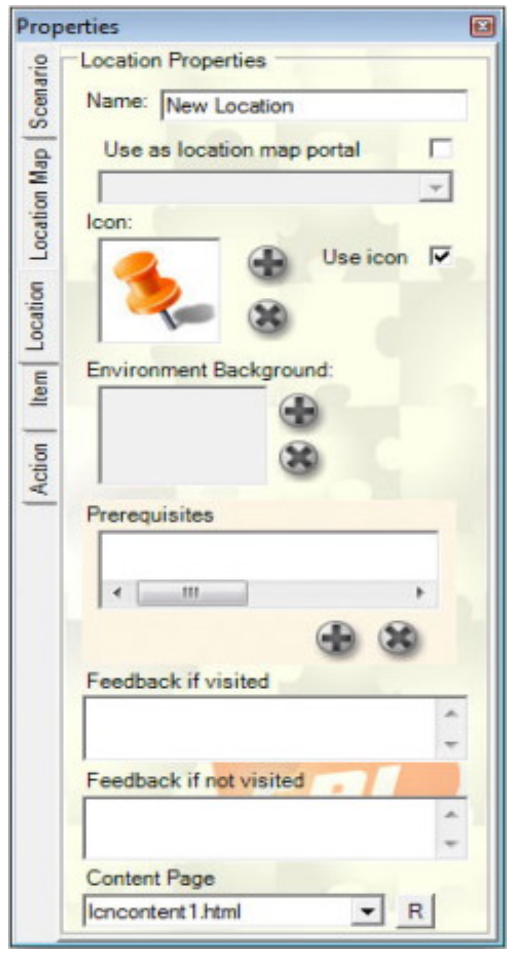

Figure 4: The SBLi Properties Panel

When in builder mode, the floating properties panel (shown in Figure 4) is visible allowing the scenario author to perform a number of functions associated with the construction and design of a scenario. As shown in Figure 4, there are 5 tabs on the left 
of the panel that allow the author to set properties for the Scenario, Location map (where the author uses nested locations in the scenario - see below), Location, Item and Action. The Location tab has been selected in Figure 4, showing the specific properties that can be determined for a specific location.

\section{Operational features of SBLi}

Although any simulated scenario will inevitably be a simplification of reality, SBLi has been designed to include a number of operational features that allow scenario authors to increase the realism they can incorporate in their scenarios, and provide an experience that is more characteristic of real world events. The main properties of these operational features are described below. Most of them can be introduced into a scenario via the properties panel while others are activated via the SBLi windows. Full details of the features included in SBLi can be found in the Builder and Player help documents that can be accessed in the support section on the SBLi site (The University of Queensland, 2012).

\section{Nested locations}

The SBLi Builder allows scenario authors to create nested locations within a scenario, enabling a number of main and subsidiary locations to be included in the location window. For example, in one SBLi scenario, where the learner acts as a social worker who has to assess the competency of an elderly lady to live on her own, the initial location window has icons representing a hospital, the social work office and the elderly lady's home. After visiting the patient in hospital, the learner visits the patient when she has returned home. By clicking on this home location in the initial Location window a new "home" location window appears that shows different locations that can be visited within the home such as the bedroom, bathroom, and lounge room. Various items and actions are associated with each of these nested locations, allowing an assessment of the patient's competency to live alone. To leave the home the scenario author has added a location - "Exit home" - which returns the learner to the original set of locations.

\section{Collecting items}

In the real world, certain actions can only be carried out in particular locations where specific items or tools are available in that location. For instance, a quarantine officer needs to collect and take appropriate documents, a field manual and equipment to a wharf in order to competently inspect and process a new shipment of imported produce. To enable items to be collected in an SBLi scenario, the author needs to tick a box on the Item tab in the Properties panel indicating that the specific item can be collected. The learner, in the role of a quarantine officer, can then collect that item by clicking and dragging the item to a square collection box in the lower part of the Environment Window in the SBLi Player. These collected items are stored and can be viewed and retrieved (uncollected) from the Collection window when other locations are visited.

\section{Monetary and time budgets}

An important learning objective for some scenarios is the importance of considering the time or monetary costs associated with different actions before deciding on which 
action to take. This feature is incorporated in SBLi by providing scenario authors with the ability to allocate time and/or monetary costs to particular actions and to set a total time or monetary budget within which the student has to operate. These costs are then incurred when students take actions within the scenario: once the budget limit has been reached, no further actions can be taken.

Apart from the obvious use of monetary costs and financial budgets in business or consumer scenarios, this facility has been used in other ways, including a scenario to assess the critical thinking skills of undergraduate law students. Given a limited time budget, the challenge for learners is to ask critical questions of a client concerning the specific legal issue involved. Each of the possible questions that can be asked has a related time cost that reflects the time taken to ask that question and to get a response from the client. Students need to think critically about which set of questions to ask within the budgeted time limit in order to obtain the most relevant information for deciding on the best way to proceed.

\section{Prerequisites}

In real life situations access to Locations, Items and Actions may depend on one or more conditions. For instance, in the quarantine case described above, a quarantine officer cannot make a proper inspection or take appropriate action regarding an imported shipment without collecting and taking appropriate forms and equipment to the wharf. In other scenarios, the range of options open to the learner may depend on locations previously visited or not visited, items previously observed or collected, or actions previously performed.

A pre-requisite "wizard" or builder enables SBLi scenario authors to hide or reveal locations, items or actions depending on specific conditions or prerequisites. Authors can use this wizard to construct prerequisites through a series of drop down menus, as shown in the quarantine example in Figure 5. The conditions for making an inspection are set by completing the sentence: "I want this action": "Inspect produce" to be available if ... "the Item", "Magnifying lens" "has been" "collected", where each parameter is defined by selecting these terms from the drop down menus. Note that more than one prerequisite can be added, allowing far more control over the conditions set on scenario processes.

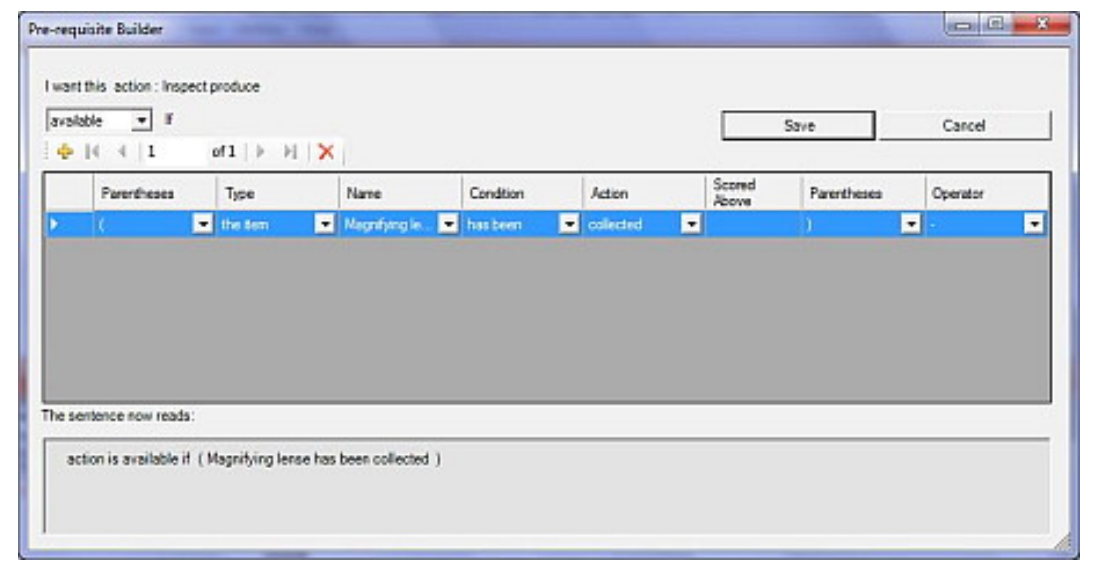

Figure 5: Pre-requisite builder for constructing pre-requisites in the SBLi Builder 


\section{Report item}

Teachers often wish to test learners as they work their way through a scenario, either to evaluate their performance or to provide immediate feedback to make sure they understand key concepts before proceeding through the scenario. SBLi provides scenario authors with a report item module that is accessed from the Content window tool bar (Figure 3) and allows authors to create and insert a quiz or a fill-in box for a larger report at any stage in a scenario. Essentially a web form, the report item consists of a template that is customised by the author and allows different types of questions to be included, including multiple choice, checked choice or text based questions. Figure 6 shows the template for a multiple-choice question and indicates how the author can customise the report item.

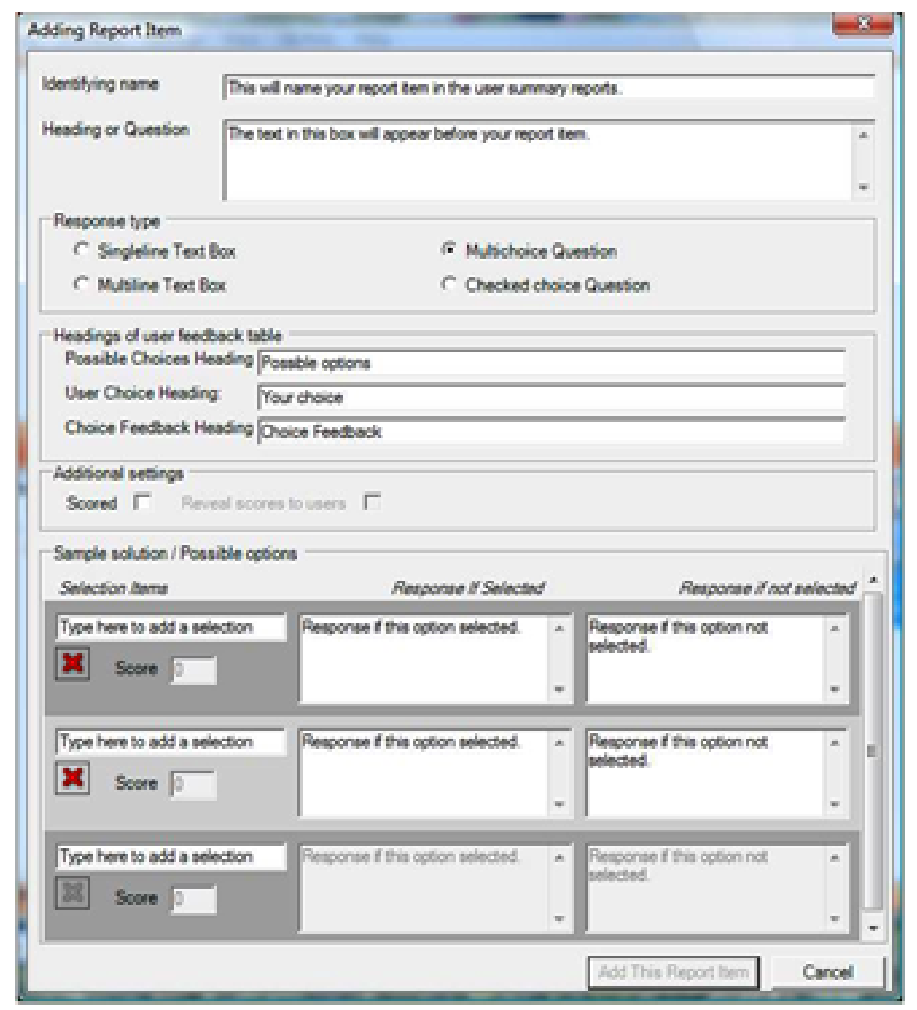

Figure 6: Template for designing a report item, in this case showing a multiple choice question

Once submitted, the scenario author has a number of options for using these results:

- The submitted report can be kept with the overall scenario report in the user log (see below) and accessed together with other tracking information by the teacher or trainer.

- The learner can be given immediate feedback which, in the case of multiple and checked-choice questions, will depend on the answer(s) given (See Figure 6).

- A score for correct answers can be set so that the user can only continue through the scenario once a total, threshold score has been reached. 


\section{User logs}

Another important reporting feature of SBLi is the ability to track the decisions and responses of learners as they work through a scenario. Once tracking of users has been set, a unique User log for each user can be accessed, providing valuable information on the real time taken interacting with the scenario; which locations were visited and for how long; what actions were taken; the responses to all questions; etc. As well as providing a means of student assessment and capturing research data, this user log can also be viewed online so that the progress of students working on the scenario can be determined. Reviewing these logs enable educators to assess the student's understanding of the scenario's content and concepts.

The user log can also be used to provide feedback to learners once they have come to the end of a scenario. For example, authors may wish to confirm that the student made the correct decision to visit a specific location or that it was an unnecessary visit; alternatively, feedback can be given if a location was not visited or if an item was not collected or examined.

\section{The SBLI Server software}

As previously mentioned, scenarios developed using the SBLi Builder can be distributed and deployed for use by learners on CD/DVD, via a local network, or online, in which case learners only need a web browser to access SBLi scenarios. Examples of online scenarios can be accessed at the SBLi web site (The University of Queensland, 2012). SBLi server software has been developed to deploy scenarios on the Internet, consisting of an online player and a scenario management module.

\section{The online player}

Is very similar to the computer based player, although there are a number of feature differences designed to enhance the online delivery of scenarios (see Features table in Appendix). Scenarios deployed using the online player can be made publicly available or restricted to particular groups of users. User groups are defined by parameters set by educators within the Server's management module. One special feature of the online player is that users have the ability to save a scenario session and return to the same point at a later time.

The server management module

This allows scenario developers to:

- Host scenarios on their own institution's Internet/Intranet server.

- Manage user access to individual scenarios

- Obtain user logs that track every decision/pathway the user took in the scenario.

- Receive submitted reports from users through the lecturer's email or from the server.

- Manage user groups, including creating, updating, and deleting user groups.

- Manage scenarios, including uploading new or updated scenarios and providing scenario details, such as the title, description, author, category, and groups who can access the scenario.

- Scenario searching: search for and view scenarios based on criteria such as scenario name, category, target audience and author/s.

The latest version of the server management module (version 2), which includes a web service component, an Application Programming Interface (API), has been open 
sourced. This allows institutions to customise or develop their own scenario management application or easily integrate it with other e-learning platforms such as Blackboard and Moodle. SBLi has already been partially integrated with Blackboard, allowing students and teachers to use the online player without requiring reauthentication, while colleagues at Massey University are working on the integration of SBLi with Moodle.

\section{Scenario design}

Although SBLi provides an authoring tool which allows the easy construction of interactive scenarios, the design of these exercises, and the lessons that support them, is achieved through a variety of approaches. It is very much a creative process, with endless ways in which scenarios can be planned, designed and crafted to enhance learning. A full discussion of this design process is beyond the scope of this paper but it essentially consists of four main steps:

Step 1. Specify and design the scenario according to the following: the target audience and learning objectives; whether it be to develop problem solving skills or raise ethical or moral issues; the context in which the scenario will be used, such as a tutorial, a prelude to a field trip, or a lab exercise; and the various features of SBLi which will assist the learning process.

Step 2. Determine the scenario flow, write the content, and test the framework in SBLi. As it is important to establish the boundaries of the scenarios and not overcomplicate the learning process, the SBLi website provides several planning templates plus a mind mapping template. Whilst not prescriptive, these instructions provide an adaptable resource that can assist in planning scenarios and generate ideas on scenario structure.

Step 3. Take and/or obtain photographs, videos, create icons, or develop other multimedia components.

Step 4. Incorporate the scenario into SBLi and test and edit the scenario before final release.

Stewart (2011b) elaborated on the design steps above, using simple planning tools such as short, table-based descriptors for lesson specifications, flow diagrams for specifying activities, locations and prerequisites, and document-based schemas for crafting the content prior to entry into the SBLi builder. Detailing the scenario content, structure and specifications in common formats such as Microsoft Word documents prior to authoring allows the scenario to be seen as a whole, aids collaboration and allows the scenario content to be easily re-used / repackaged in another delivery tool.

\section{How SBLi is being used}

A review of SBLi scenarios created to date shows a diverse range of target users, including secondary school students (Blackburn, 2011), university students and inservice learners. It is also apparent that there are numerous ways in which the features of SBLi are being used to meet specific learning objectives. The brief description of a small selection of scenarios given in Table 1, organised on the basis of discipline, indicates some of the different and novel ways in which SBLi scenarios have been used 
for secondary, tertiary and professional learning. Further information about some of the scenarios that are publicly available on the Internet can be obtained by following the links provided in Table 1. Links to other scenarios are provided by Stewart (2011a) and The University of Manchester (2011).

As SBLi is relatively new, there are few studies that assess its impact on student learning. In fact, assessing impact on student learning by SBLi itself is very hard to gauge since an SBLi experience from the learner's perspective is not purely the SBLi software, but also depends on the SBLi scenario being delivered and how well it has been incorporated and scaffolded into a lesson. SBLi is simply a tool and, like all tools, it can be used effectively or poorly by those who create scenarios.

Nevertheless, studies of the reception and impact of SBLi scenarios are starting to appear. A survey of third year undergraduate students at The University of Queensland was conducted after they had worked through a series of Occupational Health and Safety (OH\&S) scenarios. The results, shown in Figure 7, indicate that around $80 \%$ of students generally found the scenarios easy to use and enjoyable.

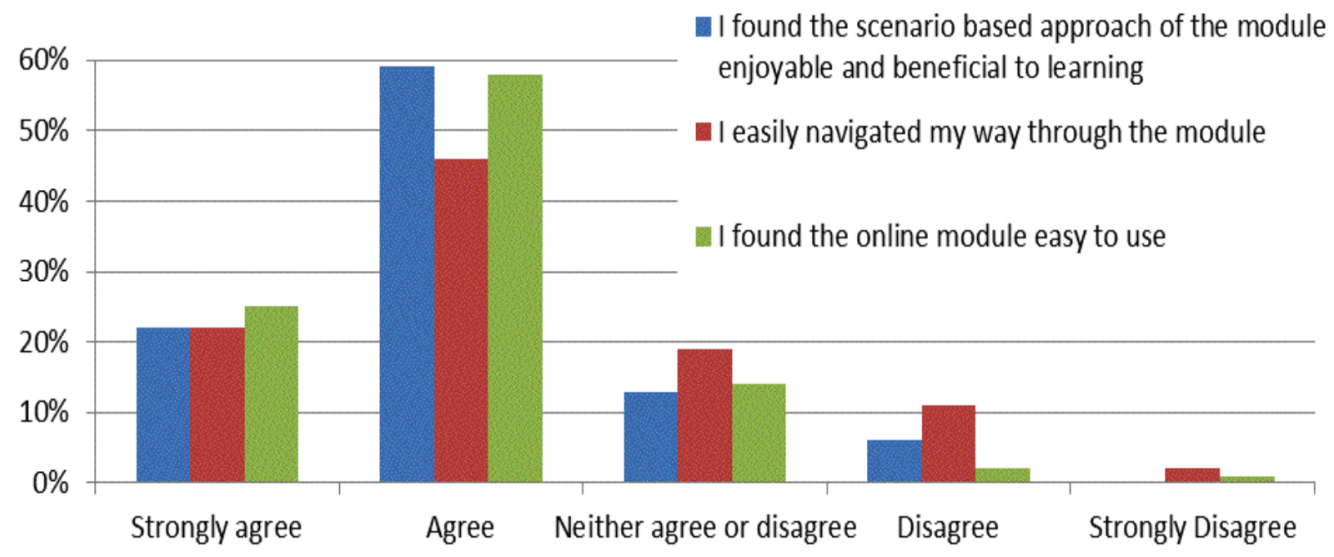

Figure 7: Feedback on the SBLi OH\&S scenarios from 85 students (Jinks, A. (2012) personal communication)

In a more detailed study, Seddon, McDonald and Schmidt (2012) investigated the performance of student cohorts from a second-year genetics course for undergraduate veterinary students, where SBLi was used to deliver scenario-based lessons (SBL). Comparison of learning outcomes from SBL-supported and non-SBL-supported content (within and across student cohorts) indicated that exposure to SBL generated quantifiable improvements in learning in both high and low ability students.

More relevant to the effectiveness of the tool itself would be research into teacher use for developing, publishing and using scenarios. No formal studies are known to the authors. However SBLi is now embedded in several teaching universities as part of their e-learning toolkit, which would indicate some satisfaction on the part of teachers and e-learning administrators. 
Table 1: A selection of SBLi scenarios to illustrate the range of target audiences, learning objectives and approaches employed

(After Jinks et al., 2011. Note that access to those scenarios where a URL is indicated is best achieved by copying and pasting the URL into a browser).

\begin{tabular}{|c|c|c|c|c|}
\hline $\begin{array}{c}\text { Scenario } \\
\text { topic }\end{array}$ & $\begin{array}{l}\text { Institution(s) } \\
\text { involved }\end{array}$ & $\begin{array}{c}\text { Target } \\
\text { audience }\end{array}$ & $\begin{array}{c}\text { Main } \\
\text { features }\end{array}$ & $\begin{array}{c}\text { Link if } \\
\text { publically viewable }\end{array}$ \\
\hline \multicolumn{5}{|l|}{ Agriculture } \\
\hline $\begin{array}{l}\text { Native } \\
\text { plants }\end{array}$ & $\begin{array}{l}\text { The } \\
\text { University of } \\
\text { Queensland } \\
\text { (Gatton } \\
\text { campus) }\end{array}$ & $\begin{array}{l}\text { Existing and } \\
\text { potential } \\
\text { entrants to the } \\
\text { industry }\end{array}$ & $\begin{array}{l}\text { Series of scenarios to assist in } \\
\text { planning and managing a } \\
\text { floriculture enterprise; } \\
\text { incorporates spreadsheet } \\
\text { links; deployed on CD and } \\
\text { Internet. }\end{array}$ & $\begin{array}{l}\text { http://tinyurl.com/ } \\
\text { 6nqwrhb }\end{array}$ \\
\hline $\begin{array}{l}\text { Quarantine } \\
\text { procedures }\end{array}$ & $\begin{array}{l}\text { The } \\
\text { University of } \\
\text { Queensland }\end{array}$ & $\begin{array}{l}\text { Students and } \\
\text { new quarantine } \\
\text { officers (espec- } \\
\text { ially in develop- } \\
\text { ing countries) }\end{array}$ & $\begin{array}{l}\text { User acts as a quarantine } \\
\text { officer required to inspect a } \\
\text { new shipment with the aim } \\
\text { of learning about relevant } \\
\text { documents and procedures. }\end{array}$ & $\begin{array}{l}\text { http:// tinyurl.com/ } \\
\text { 7p7kklz }\end{array}$ \\
\hline \multicolumn{5}{|c|}{ Business studies } \\
\hline Statistics & $\begin{array}{l}\text { The } \\
\text { University of } \\
\text { Queensland }\end{array}$ & $\begin{array}{l}\text { The University } \\
\text { of Queensland } \\
\text { and Manchester } \\
\text { undergraduates }\end{array}$ & $\begin{array}{l}\text { Series of scenarios } \\
\text { illustrating statistical } \\
\text { principles based on a specific } \\
\text { PBL case study. }\end{array}$ & \\
\hline \multicolumn{5}{|l|}{ Engineering } \\
\hline $\begin{array}{l}\text { A traffic } \\
\text { speed } \\
\text { survey }\end{array}$ & $\begin{array}{l}\text { The } \\
\text { University of } \\
\text { Queensland }\end{array}$ & $\begin{array}{l}\text { The University } \\
\text { of Queensland } \\
\text { undergraduates }\end{array}$ & $\begin{array}{l}\text { The user plays the role of a } \\
\text { junior traffic engineer who } \\
\text { has to undertake and analyse } \\
\text { a traffic speed survey. }\end{array}$ & \\
\hline $\begin{array}{l}\text { Engineers } \\
\text { without } \\
\text { Borders } \\
\text { (EwB) }\end{array}$ & $\begin{array}{l}\text { The } \\
\text { University of } \\
\text { Queensland }\end{array}$ & $\begin{array}{l}\text { Australian } \\
\text { undergraduate } \\
\text { students }\end{array}$ & $\begin{array}{l}\text { A series of two scenarios } \\
\text { based on EwB projects. Users } \\
\text { work through a number of } \\
\text { local settings in SE Asia. } \\
\text { Provides multimedia } \\
\text { material for student projects } \\
\text { in Australian universities. }\end{array}$ & $\begin{array}{l}\text { http:// tinyurl.com/ } \\
\text { 73zhpmq }\end{array}$ \\
\hline \multicolumn{5}{|l|}{ Law } \\
\hline \begin{tabular}{|l|} 
Client \\
consultation \\
(showcased)
\end{tabular} & $\begin{array}{l}\text { The } \\
\text { University of } \\
\text { Queensland }\end{array}$ & $\begin{array}{l}\text { The University } \\
\text { of Queensland } \\
\text { undergraduates }\end{array}$ & $\begin{array}{l}\text { A series of scenarios that use } \\
\text { time budgets when } \\
\text { interviewing a client to } \\
\text { improve students' critical } \\
\text { thinking skills. }\end{array}$ & \\
\hline $\begin{array}{l}\text { Enduring } \\
\text { Power of } \\
\text { Attorney } \\
\text { issues }\end{array}$ & $\begin{array}{l}\text { Queensland } \\
\text { Legal } \\
\text { Services } \\
\text { Commission } \\
\text { (QLSC); The } \\
\text { University of } \\
\text { Queensland }\end{array}$ & $\begin{array}{l}\text { Professional } \\
\text { solicitors; } \\
\text { undergraduates }\end{array}$ & $\begin{array}{l}\text { A series of three scenarios in } \\
\text { which the user observes a } \\
\text { solicitor dealing with a legal } \\
\text { issue involving an elderly } \\
\text { family member. }\end{array}$ & $\begin{array}{l}\text { http:// tinyurl.com/ } \\
\text { 7t73yrc } \\
\text { http:/ / tinyurl.com/ } \\
\text { 6mjnfr6 } \\
\text { http:/ / tinyurl.com/ } \\
\text { 7gl9rt9 }\end{array}$ \\
\hline $\begin{array}{l}\text { Suburban } \\
\text { solicitor's } \\
\text { week }\end{array}$ & $\begin{array}{l}\text { QLSC; } \\
\text { Queensland } \\
\text { University of } \\
\text { Technology } \\
\text { (QUT); The } \\
\text { University of } \\
\text { Queensland }\end{array}$ & $\begin{array}{l}\text { Professional } \\
\text { solicitors; } \\
\text { under- } \\
\text { graduates }\end{array}$ & $\begin{array}{l}\text { The user plays the role of a } \\
\text { solicitor who is faced with } \\
\text { ethical issues during the } \\
\text { course of a week. }\end{array}$ & $\begin{array}{l}\text { http:// tinyurl.com/ } \\
\text { 6wep3fn }\end{array}$ \\
\hline
\end{tabular}




\begin{tabular}{|c|c|c|c|c|}
\hline $\begin{array}{c}\text { Scenario } \\
\text { topic }\end{array}$ & $\begin{array}{c}\text { Institution(s) } \\
\text { involved }\end{array}$ & $\begin{array}{c}\text { Target } \\
\text { audience }\end{array}$ & $\begin{array}{c}\text { Main } \\
\text { features }\end{array}$ & $\begin{array}{c}\text { Link if } \\
\text { publically viewable }\end{array}$ \\
\hline \multicolumn{5}{|c|}{ Medical and health sciences } \\
\hline $\begin{array}{l}\text { Dentistry } \\
\text { clinical and } \\
\text { procedural } \\
\text { scenarios }\end{array}$ & $\begin{array}{l}\text { The } \\
\text { University of } \\
\text { Queensland }\end{array}$ & & $\begin{array}{l}\text { Nine scenarios have been } \\
\text { created to introduce students } \\
\text { to both clinical and } \\
\text { procedural case studies in } \\
\text { the dental field. }\end{array}$ & \\
\hline $\begin{array}{l}\text { Paediatrics } \\
\text { (showcased) }\end{array}$ & $\begin{array}{l}\text { Royal } \\
\text { Brisbane } \\
\text { Children's } \\
\text { Hospital; The } \\
\text { University of } \\
\text { Queensland }\end{array}$ & $\begin{array}{l}\text { First year } \\
\text { doctors }\end{array}$ & $\begin{array}{l}\text { Simulated triage process for } \\
\text { three child patients }\end{array}$ & \\
\hline $\begin{array}{l}\text { Physiology } \\
\text { in clinical } \\
\text { contexts } \\
\text { (showcased) }\end{array}$ & $\begin{array}{l}\text { The } \\
\text { University of } \\
\text { Queensland }\end{array}$ & $\begin{array}{l}\text { Under- } \\
\text { graduates }\end{array}$ & $\begin{array}{l}\text { Scenario aimed at improving } \\
\text { diagnostic reasoning skills } \\
\text { with learning modules (Flash } \\
\text { animations, etc.) included. }\end{array}$ & \\
\hline $\begin{array}{l}\text { Phonological } \\
\text { awareness }\end{array}$ & $\begin{array}{l}\text { The } \\
\text { University of } \\
\text { Queensland } \\
\text { School of } \\
\text { Health \& } \\
\text { Rehabilitation }\end{array}$ & $\begin{array}{l}\text { Continuing } \\
\text { professional } \\
\text { development }\end{array}$ & $\begin{array}{l}\text { Three scenarios to assist } \\
\text { facilitators in becoming } \\
\text { proficient in screening and } \\
\text { assessing phonological } \\
\text { issues. }\end{array}$ & \\
\hline Nutrition & $\begin{array}{l}\text { The } \\
\text { University of } \\
\text { Queensland } \\
\text { School of } \\
\text { Population } \\
\text { Health }\end{array}$ & $\begin{array}{l}\text { Continuing } \\
\text { professional } \\
\text { development }\end{array}$ & $\begin{array}{l}\text { A series of scenarios that put } \\
\text { students in the role of a } \\
\text { nutritionist for } \\
\text { various public health } \\
\text { nutrition programs. }\end{array}$ & \\
\hline $\begin{array}{l}\text { OH\&S } \\
\text { Fun and } \\
\text { Danger - } \\
\text { Getting the } \\
\text { mix right }\end{array}$ & $\begin{array}{l}\text { The } \\
\text { University of } \\
\text { Queensland }\end{array}$ & $\begin{array}{l}\text { Exit level } \\
\text { university } \\
\text { students - } \\
\text { relevant to their } \\
\text { preparation for } \\
\text { professional } \\
\text { practice. }\end{array}$ & $\begin{array}{l}\text { To help gain an } \\
\text { understanding of OH\&S } \\
\text { responsibilities in the } \\
\text { workplace. }\end{array}$ & \\
\hline \multicolumn{5}{|l|}{ Science } \\
\hline Genetics & $\begin{array}{l}\text { Manchester } \\
\text { University, } \\
\text { UK }\end{array}$ & $\begin{array}{l}\text { Manchester and } \\
\text { UK under- } \\
\text { graduates }\end{array}$ & $\begin{array}{l}\text { Students investigate the } \\
\text { genetics of "Chocolate } \\
\text { monsters" using SBLi } \\
\text { functions to breed biotypes, } \\
\text { and analyse results; available } \\
\text { as an UK Open Educational } \\
\text { Resource. }\end{array}$ & $\begin{array}{l}\text { http://sbli.ls.manch } \\
\text { ester.ac.uk/OER/ }\end{array}$ \\
\hline $\begin{array}{l}\text { Marine } \\
\text { Science }\end{array}$ & $\begin{array}{l}\text { The } \\
\text { University of } \\
\text { Queensland }\end{array}$ & $\begin{array}{l}\text { The University } \\
\text { of Queensland } \\
\text { undergraduate } \\
\text { students }\end{array}$ & $\begin{array}{l}\text { Virtual field course, } \\
\text { including site selection, } \\
\text { sampling, identification, and } \\
\text { statistics - all the activities } \\
\text { involved in the real thing. }\end{array}$ & $\begin{array}{l}\text { http:/ / tinyurl.com/ } \\
\text { 72xbkwe }\end{array}$ \\
\hline $\begin{array}{l}\text { Nerve action } \\
\text { potential }\end{array}$ & $\begin{array}{l}\text { The } \\
\text { University of } \\
\text { Queensland }\end{array}$ & $\begin{array}{l}\text { The University } \\
\text { of Queensland } \\
\text { undergraduate } \\
\text { students }\end{array}$ & $\begin{array}{l}\text { A scenario front end linking } \\
\text { to "L-systems" modelling } \\
\text { software allowing students } \\
\text { to explore nerve action } \\
\text { processes by changing model } \\
\text { parameters. }\end{array}$ & \\
\hline
\end{tabular}




\begin{tabular}{|c|c|c|c|c|}
\hline $\begin{array}{c}\text { Scenario } \\
\text { topic }\end{array}$ & $\begin{array}{c}\text { Institution(s) } \\
\text { involved }\end{array}$ & $\begin{array}{c}\text { Target } \\
\text { audience }\end{array}$ & $\begin{array}{c}\text { Main } \\
\text { features } \\
\end{array}$ & $\begin{array}{c}\text { Link if } \\
\text { publically viewable }\end{array}$ \\
\hline Pond Life & $\begin{array}{l}\text { Southbank } \\
\text { TAFE, } \\
\text { Brisbane }\end{array}$ & $\begin{array}{l}\text { Teacher } \\
\text { trainees, } \\
\text { secondary } \\
\text { school students }\end{array}$ & $\begin{array}{l}\text { Virtual field course including } \\
\text { sampling and identification; } \\
\text { incorporating PowerPoint } \\
\text { module, animations; inter- } \\
\text { active identification key, etc. }\end{array}$ & \\
\hline $\begin{array}{l}\text { Vertebrate } \\
\text { pest } \\
\text { management }\end{array}$ & $\begin{array}{l}\text { University of } \\
\text { Canberra; } \\
\text { CRC for } \\
\text { Invasive } \\
\text { Vertebrate } \\
\text { Pests }\end{array}$ & $\begin{array}{l}\text { Secondary } \\
\text { school students } \\
\text { in Canberra } \\
\text { ACT }\end{array}$ & $\begin{array}{l}\text { Series of scenarios to } \\
\text { illustrate ecological and } \\
\text { social aspects involved in } \\
\text { understanding and } \\
\text { managing six different } \\
\text { vertebrate pest problems. }\end{array}$ & $\begin{array}{l}\text { http:/ / tinyurl.com/ } \\
\text { 73wb715 }\end{array}$ \\
\hline Water4Life & $\begin{array}{l}\text { NSW Science } \\
\text { Teachers } \\
\text { Association; } \\
\text { NSW Govt; } \\
\text { Sydney } \\
\text { Water }\end{array}$ & $\begin{array}{l}\text { Secondary } \\
\text { school students } \\
\text { in NSW }\end{array}$ & $\begin{array}{l}\text { A series of four scenarios } \\
\text { providing information, } \\
\text { projects on a wide range of } \\
\text { water issues; distributed as } \\
\text { CDs to NSW schools as well } \\
\text { as on the Internet. }\end{array}$ & $\begin{array}{l}\text { http:/ / tinyurl.com/ } \\
\text { c61398r }\end{array}$ \\
\hline \multicolumn{5}{|c|}{ Social and behavioural studies } \\
\hline $\begin{array}{l}\text { Social Needs } \\
\text { Education }\end{array}$ & $\begin{array}{l}\text { The } \\
\text { University of } \\
\text { Queensland }\end{array}$ & $\begin{array}{l}\text { The University } \\
\text { of Queensland } \\
\text { undergraduates }\end{array}$ & $\begin{array}{l}\text { A scenario that requires the } \\
\text { user to develop an individ- } \\
\text { ual educational plan for a } \\
\text { specific (virtual) student. }\end{array}$ & \\
\hline \multicolumn{5}{|c|}{ Veterinary science } \\
\hline $\begin{array}{l}\text { Virtual } \\
\text { Veterinary } \\
\text { hospital }\end{array}$ & $\begin{array}{l}\text { Massey } \\
\text { University, } \\
\text { New Zealand }\end{array}$ & $\begin{array}{l}\text { Massey under- } \\
\text { graduates }\end{array}$ & $\begin{array}{l}\text { Numerous scenarios devel- } \\
\text { oped using data template; } \\
\text { No restrictions on diagnostic } \\
\text { options; Three scenarios } \\
\text { used as part of final 5th year } \\
\text { examination. }\end{array}$ & \\
\hline $\begin{array}{l}\text { Virtual } \\
\text { Practitioner }\end{array}$ & $\begin{array}{l}\text { The } \\
\text { University of } \\
\text { Queensland }\end{array}$ & $\begin{array}{l}\text { The University } \\
\text { of Queensland } \\
\text { undergraduates }\end{array}$ & $\begin{array}{l}\text { Series of scenarios; Custom- } \\
\text { ised server and collections } \\
\text { tab modified to "Patient file" }\end{array}$ & \\
\hline
\end{tabular}

\section{Discussion}

By giving students a rich exploratory online environment, SBLi supports the active learning pedagogies cited at the beginning of this paper. In particular, the prerequisite functionality means that content can either be explored at will, or revealed or hidden, depending on the learners' selections. Added to this, the ability to allocate both time and monetary values to any investigative activity reflects real world consequences. Report items allow for summative and formative assessment. Also, the ability to hyperlink to any other Internet resource means learners can leave the SBLi scenario for further information and tasks, such as online groupwork in an LMS.

Navigating large online learning spaces can be cognitively exacting and it is easy for learners to get lost as they explore and acquire information (Liang \& Sedig, 2009). The split screen interface, consisting of location, environment, action/collection and scenario content windows, allows learners to visualise exactly where they are during the exercise.

While the emphasis of this paper has been on the design and functionality of SBLi and the various ways in which this specialised e-learning software package is being used across a range of disciplines, there are a number of practical issues we have had to deal 
with in sustaining our involvement with scenario based learning tools over the past 15 years. These include support and funding issues, both of which have been critical in implementing and sustaining these tools. These issues, important for all e-learning tools of this nature, are discussed below.

\section{The importance of support}

SBLi has been designed to enable teachers not familiar with programming to be able to easily create complex and attractive scenarios, with consequent benefits in terms of the comparatively low costs or the staff time required to produce a scenario. Technical support for SBLi authors is provided through Builder Help and Player Help; an email/phone Help Desk at The University of Queensland; and the development of a dedicated web site and forum (The University of Queensland, 2012).

From our experience, however, further support is often required for planning the scenario and the lesson context in which it will be used. Tertiary teachers, for example, face many barriers when it comes to developing new, electronically-delivered courseware; most important is a lack of time, knowledge of pedagogy, and of training in this area (Stewart, 2011b). In many cases, an effective and professional looking scenario, that utilises the full capability of the software, is only likely to be achieved where the teacher can access instructional design, graphic design and multimedia production support. Experience with SBLi scenario development at The University of Queensland and at the University of Canberra in Australia, at Massey University in New Zealand and at the University of Manchester in the UK has shown that a dedicated support team, together with innovative and inspired teachers, has been a critical factor in embedding innovative, SBLi-facilitated scenario-based lessons as an important component in student learning activities.

Apart from the benefits that SBLi clients gain from this support, those involved in developing and supporting SBLi also gain important benefits. The feedback from those creating scenarios in a variety of ways, across different disciplines, and aimed at a spectrum of learners, from primary, secondary and tertiary students to those involved in professional in-service training, provides an appreciation of issues that need better support, and where new or improved functionality of SBLi needs to be developed.

For instance, our initial "model" of a scenario came from our involvement with diagnosing crop problems; this paradigm clearly has wide application in medicine, veterinary science, and in diagnosing "sick" businesses. SBLi has also been used in many other ways, however, such as providing a "virtual" marine field course experience, and engaging students in scenarios that raise moral, ethical and religious issues (see Table 1). SBLi has also been used in ways we had not envisaged. For instance, in one scenario of a series aimed at improving students' understanding of genetics, learners can collect different biotypes of a hypothetical species (a chocolate monster), take them to a laboratory and breed them to determine the genetic features of the offspring (Breakey, Levin, Miller \& Hentges, 2008). In becoming aware of these different applications of SBLi, we have made important changes to SBLi Version 2 to broaden its generic functionality (see Appendix).

\section{Resourcing and sustainability issues}

One of the reasons for designing and developing SBLi as a generic teaching tool was to increase its cost effectiveness: the broader the application of the software to a very 
wide range of disciplines, the greater the learning benefit per dollar spent on development or the greater the potential market for the software. This strategy has enabled us to be involved in developing and supporting the use of scenario based learning software for over 15 years, with funds from a variety of sources, including commercial licences, grants and contracts.

While this mix of funding sources has provided some flexibility in covering our costs, it is grants, both internal and external to The University of Queensland, that have made the major contribution. In light of this, we have recently revised our funding strategy. The SBLi Builder and Player application and the server scenario management module are now provided free for non-commercial educational use. Also, as mentioned earlier, the server scenario management module is now both free and open sourced, enabling large institutions to easily integrate the SBLi Server within their own network and security environments, as well as providing other benefits. Details of the new licencing arrangements can be found on the SBLi website (The University of Queensland, 2012).

Under this new arrangement, our strategy is to increase our links with those currently using SBLi in Australia, New Zealand, the UK and other countries, to encourage other institutions to join the SBLi community and be involved in the collaborative development and sharing of scenarios. Already, the Life Sciences team at The University of Manchester have made five SBLi scenarios on genetic analysis, described above, available to all universities in the UK as part of an Open Educational Resource (OER) project (The University of Manchester, 2011). As well as providing online access to the scenarios, the builder files of these scenarios are also available to any university that wants to adapt them for their own purposes, enabling these other universities to integrate the scenarios within their specific courses and learning management systems. To encourage further OER developments, our future plans include the development of additional features on the SBLi web site to help facilitate increased collaboration through the sharing of scenarios and multimedia resources.

\section{References}

Barrows, H. S. \& Tamblyn, R. M. (1980). Problem-based learning: An approach to medical education. Springer Publishing company, New York.

Blackburn, G. (2011). The eLearning scenario: Technology and contemporary learning. Teacher, April, No. 220, pp39-42.

Breakey, K M., Levin, D., Miller, I. \& Hentges, K. E. (2008). The use of scenario-based-learning interactive software to create custom virtual laboratory scenarios for teaching genetics. Genetics, 179, 1151-1155. http:/ / dx.doi.org/10.1534/genetics.108.090381

Brown, J. S., Collins, A. \& Duguid, P. (1989). Situated cognition and the culture of learning. Educational Researcher, 18(1), 32-42. http:/ / dx.doi.org/10.3102/0013189X018001032

Christensen, C. R. \& Hansen A. J. (1981). Teaching and the case method. Boston: Harvard Business School Publishing Division.

Herrington, J. Reeves, T. \& Oliver, R. (2004). Online learning as information delivery: Digital myopia. Journal of Interactive Learning Research, 16(4), 353-367. http: / / ro.uow.edu.au / cgi / viewcontent.cgi?article=1032\&context=edupapers

Hmelo-Silver, C. E. (2004). Problem-based learning: What and how do students learn? Educational Psychology Review, 16(3), 235-266. http: / / dx.doi.org/ 10.1023/B:EDPR.0000034022.16470.f3 
Jinks, A., Norton, G., Taylor, M. \& Stewart, T. (2011). Scenario-based learning: Experiences in the development and application of a generic teaching software tool. In D. Holt, S. Segrave \& J. Cybulski (Eds.), Professional education using e-simulations: Benefits of blended learning design. Chapter 19 (pp. 346-369). IGI Global Press.

Kuhn, D., Black, J., Keselman, A. \& Kaplan, D. (2000). The development of cognitive skills to support inquiry learning. Cognition and Instruction, 18(4), 495-523. http: / / dx.doi.org/10.1207/S1532690XCI1804_3

Liang, G. \& Sedig, K. (2009). Characterizing navigation in interactive learning environments. Interactive Learning Environments, 17(1), 53-75. http: / / dx.doi.org/10.1080/ 10494820701610605

Schank, R., Fano, A., Bell, B. \& Jona, M. (1993). The design of goal-based scenarios. Journal of the Learning Sciences, 3(4), 305-345. http: / / www.jstor.org/ stable/1466619

Seddon, J. M., McDonald, B. \& Schmidt, A. L. (2012). ICT-supported, scenario-based learning in preclinical veterinary science education: Quantifying learning outcomes and facilitating the novice-expert transition. Australasian Journal of Educational Technology, 28(2), 214-231. http:/ / www.ascilite.org.au/ajet/ajet28/ seddon.html

Stewart T. M. (1992). Diagnosis: A microcomputer-based teaching-aid. Plant Disease, 76(6), 644647. http:/ / www.apsnet.org/publications / PlantDisease/BackIssues / Documents / 1992Articles/PlantDisease76n06_644.PDF

Stewart, T. M. (2007). Tools and techniques for scenario-based e-learning for New Zealand tertiary students: Prototype to adoption. In ICT: Providing choices for learners and learning. Proceedings ascilite Singapore 2007.

http: / / www.ascilite.org.au/conferences/ singapore07/procs/ stewart-t.pdf

Stewart T. M. (2011a). Some SBLi public scenarios now available without log in http: / / akoaotearoa.ac.nz/ community / tools-and-techniques-scenario-based-elearning/resources/pages/some-sbli-public-scenarios-/

Stewart, T. M. (2011b). Supporting the design of interactive scenarios in a university environment: Techniques, issues and constraints. In D. Holt, S. Segrave \& J. L. Cybulski (Eds.), Professional education using e-simulations: Benefits of blended learning design. Chapter 18 (pp 316-345). IGI Global Press.

Stewart, T. M. \& Bartrum, P. (2002). CHALLENGE - an authoring tool for problem-based scenarios delivered alone, or over the WWW. Proceedings of the International Conference on Computers in Education, Auckland, New Zealand (pp. 197-201). IEEE Computer Society, Los Alamitos, California. http: / / dx.doi.org/10.1109/CIE.2002.1185900

Stewart, T. M., Blackshaw, B. P., Duncan, S., Dale, M. L., Zalucki M. P. \& Norton, G. A. (1995). DIAGNOSIS - A novel, multimedia, computer-based approach to training crop protection practitioners. Crop Protection, 14(3) 241-245. http:/ / dx.doi.org/10.1016/0261-2194(95)00005-7

The University of Manchester (2011). http:/ / sbli.ls.manchester.ac.uk/OER/ViewScenarios.aspx [viewed 11 June 2012]

The University of Queensland (2011). Scenario-based Learning Interactive. http: / / www.sblinteractive.org [viewed 11 June 2012]

Virtual Patients (2011). http: / / www.elu.sgul.ac.uk/virtualpatients/ examples.htm [viewed 11 June 2012]

\section{Appendix: SBLi product feature list}




\begin{tabular}{|c|c|c|}
\hline User explorable environment & $\mathbf{Q}$ & $\bar{\nabla}$ \\
\hline Point 'n' click construction & $\mathbf{Q}$ & $\bar{\nabla}$ \\
\hline Ability to create non linear progression & $\mathbf{Q}$ & $\vec{\nabla}$ \\
\hline User collectable items & $\mathbf{Q}$ & $\nabla$ \\
\hline User tracking & $\bar{B}$ & $\bar{\nabla}$ \\
\hline Private access (Internet) & $\mathbf{Q}$ & $\bar{\nabla}$ \\
\hline Public access (Internet) & $\mathbf{Q}$ & $\nabla$ \\
\hline Set as "Play once" or unlimited & $\vec{Q}$ & $\bar{\nabla}$ \\
\hline Save and return last position & Q & $\mathbf{E}$ \\
\hline Time and money budgets & 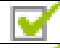 & 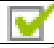 \\
\hline Personalised / instructional feedback & $\vec{\theta}$ & $\bar{\nabla}$ \\
\hline \multicolumn{3}{|l|}{ Supported operating systems } \\
\hline Windows 2000/XP/Vista/7 & $\mathbf{Q}$ & $\bar{\nabla}$ \\
\hline Mac OSX (requires software providing hardware virtualisation) & $\mathbf{Q}$ & $\nabla$ \\
\hline Linux (requires software providing hardware virtualisation) & Q & $\mathbf{E}$ \\
\hline Solaris (requires software providing hardware virtualisation) & $\mathbf{Q}$ & $\vec{\nabla}$ \\
\hline \multicolumn{3}{|l|}{ Technical } \\
\hline XML user log capturing all user activity & $\bar{Q}$ & $\bar{Q}$ \\
\hline Full export of overview or schema & $\mathbf{Q}$ & 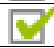 \\
\hline Online access to user logs & 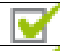 & 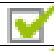 \\
\hline External editor option & $\bar{B}$ & $\vec{B}$ \\
\hline Customise skin and content & $\mathbf{Q}$ & $\nabla$ \\
\hline \multicolumn{3}{|l|}{ Multimedia support } \\
\hline HTML & $\mathbf{Q}$ & $\mathbf{\nabla}$ \\
\hline Images & Q & $\mathbf{B}$ \\
\hline Audio & $\mathbf{Q}$ & $\nabla$ \\
\hline Video & $\mathbf{Q}$ & $\mathbf{B}$ \\
\hline Other e.g. Excel, PowerPoint & 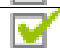 & $\mathbf{B}$ \\
\hline \multicolumn{3}{|l|}{ Media library } \\
\hline Import audio, video and images & - & $\bar{Q}$ \\
\hline Over 800 royalty free images & - & $\mathbf{Q}$ \\
\hline Create customised library & - & $\mathbf{Q}$ \\
\hline Easy search facility & - & $\bar{B}$ \\
\hline Ability to annotate images with searchable key words & - & $\mathbf{Q}$ \\
\hline \multicolumn{3}{|l|}{ Testing } \\
\hline Free form & $\bar{\nabla}$ & $\mathbf{B}$ \\
\hline Multiple choice and True/False with scoring & $\mathbf{Q}$ & $\mathbf{B}$ \\
\hline Check choice with scoring & $\vec{Q}$ & $\bar{B}$ \\
\hline Fill in the blanks with scoring & - & $\vec{\nabla}$ \\
\hline Accumulative question scores (report scores) & - & $\mathbf{B}$ \\
\hline \multicolumn{3}{|l|}{ User pathway controls (Prerequisite builder) } \\
\hline Ability to set multiple conditions using "AND" function & $\nabla$ & $\bar{\nabla}$ \\
\hline Ability to set minimum score required & $\vec{Q}$ & $\mathbf{B}$ \\
\hline Ability to set multiple conditions using "AND"; “OR" and parenthesis. & - & 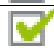 \\
\hline Conditions can be defined as available or not available & - & $\bar{\Delta}$ \\
\hline
\end{tabular}


Allows management of user accounts - create/delete/ edit

Allows management of user groups - defining things such as class groups.

Allows management of scenarios - uploading a scenario annotating with details and defining who can see which scenarios

Search facility, search for and view scenarios based on criteria such as scenario name, category / s, target audience and author/s

User log management: manage user logs related to a particular scenario. This includes viewing, searching, deleting, archiving and exporting scenario logs.

SBLi Server v2 reflects the improved functionality of the SBLi Builder v2. New user-friendly interface with new functionality. Totally redesigned the GUI (graphical user interface), making it easier for customers to manage scenarios.

A new filter to increase search options using an easy-to-use search engine.

Two different authentication modes for LDAP and non-LDAP authentication.

A new set-up package for 64 bit systems.

The new release features significantly increase performance as it has been written in a cleaner faster code base, increasing performance speed. Rewritten Help files.

Moodle and Blackboard building blocks are being developed by cooperating institutes.

Open source (supplied under General Public License, LGPL v3),

providing the following benefits:

Large institutions can easily integrate the SBLi Server within their own network and security environments; including other learning systems, such as Blackboard and Moodle.

Dependability of the code that is open to inspection;

The scenario management interface can be customised;

Integration into other learning systems, such as Blackboard and Moodle, is much easier.

\section{Online player}

Provides online delivery of scenarios

Authors: Professor Geoff Norton, Matt Taylor, Greg Blackburn, Audrey Jinks, Bahareh Razdar, Paul Holmes, Enrique Marastoni

QAAFI, Hartley Teakle Building, The University of Queensland, Brisbane Qld 4072,

Australia. Email: G.Norton@uq.edu.au, M.Taylor@uq.edu.au,

G.Blackburn@uq.edu.au, A.Jinks@uq.edu.au, B.Razdar@uq.edu.au

Web: http: / / www.sblinteractive.org/

Dr Terry Stewart, Institute of Natural Resources, College of Sciences, Massey University, Palmerston North, New Zealand. Email: T.Stewart@massey.ac.nz

Please cite as: Norton, G., Taylor, M., Stewart, T., Blackburn, G., Jinks, A., Razdar, B., Holmes, P. \& Marastoni, E. (2012). Designing, developing and implementing a software tool for scenario based learning. Australasian Journal of Educational Technology, 28(7), 1083-1102. http: / / www.ascilite.org.au/ajet/ ajet28/ norton.html 